\title{
Gambaran kadar troponin $T$ berdasarkan waktu pemeriksaan dan lokasi infark pada pasien infark miokard akut di RSUP Prof Dr. R. D. Kandou periode Januari-Desember 2015
}

\author{
${ }^{1}$ Shendy G. L. Sagala \\ ${ }^{2}$ Janry A. Pangemanan \\ ${ }^{2}$ Dewi U. Djafar
}

\author{
${ }^{1}$ Kandidat Skripsi Fakultas Kedokteran Universitas Sam Ratulangi Manado \\ ${ }^{2}$ Bagian Kardiologi Fakultas Kedokteran Unversitas Sam Ratulangi Manado \\ Email: shendygiovani@gmail.com
}

\begin{abstract}
Acute myocardial infarction (AMI) causes high mortality and morbidity rates. AMI must be dealt quickly and efficiently for prolonged ischemia can cause irreversible damage and worsen the prognosis. The American College of Cardiology decided that the diagnosis of AMI required a combination of ischemic symptoms and/or electrocardiographic changes accompanied by myocardial necrosis markers, the biomarkers. Previous studies showed that there were variations in troponin levels based on examination time and location of infarction. This study was aimed to obtain the profile of troponin $\mathrm{T}$ levels based on time of troponin $\mathrm{T}$ examination and location of infarction in AMI patients at Prof. Dr. R. D. Kandou Hospital from January to December, 2015. This was a descriptive observational study with a retrospective approach. Samples were AMI patients with complete data that fulfilled the inclusion and exclusion criteria. The results showed that of the total 61 AMI patients there were 26 samples that fulfilled the criteria. The majority of samples were males, age group 55-64 years, and the risk factor was a combination of some of the major risk factors. Most infarctions of NSTEMI were dominated by anteroseptal and anterolateral infarct locations and levels of troponin $\mathrm{T}$ were in the range of $>100-2000 \mathrm{ng} / \mathrm{L}$ (the average value of $475 \mathrm{ng} / \mathrm{L}$ ). Levels of troponin T were influenced by the time of examination, but not by the location of the infarct.
\end{abstract}

Keywords: acute myocardial infarction, troponin T, examination time, infarct location

\begin{abstract}
Abstrak: Infark miokard akut (IMA) menyebabkan angka mortalitas dan morbiditas tinggi. IMA harus ditangani dengan cepat dan efisien karena iskemia yang berkepanjangan dapat menyebabkan kerusakan yang ireversibel dan menentukan prognosis. The American College of Cardiology menetapkan bahwa untuk diagnosis infark miokard akut diperlukan kombinasi antara gejala iskemik dan/atau perubahan elektrokardiografi disertai penanda nekrosis infark yaitu biomarker. Berdasarkan penelitian sebelumnya didapatkan variasi troponin berdasarkan waktu pemeriksaan dan lokasi infark. Penelitian ini bertujuan untuk mengetahui gambaran kadar troponin $\mathrm{T}$ berdasarkan waktu pemeriksaan troponin $\mathrm{T}$ dan lokasi infark pada pasien infark miokard akut di RSUP Prof. Dr. R. D. Kandou periode Januari-Desember 2015. Jenis penelitian ialah observasional deskriptif dengan pendekatan studi retrospektif. Sampel ialah pasien infark miokard akut dengan data lengkap yang memenuhi kriteria inklusi dan eksklusi, diambil dari rekam medik. Hasil penelitian memperlihatkan dari total 61 pasien IMA didapatkan 26 sampel yang memenuhi kriteria. Mayoritas sampel ialah laki-laki, kelompok usia 55-64 tahun, faktor risiko yaitu kombinasi dari beberapa faktor risiko mayor, jenis infark NSTEMI didominasi oleh lokasi infark anteroseptal dan anterolateral dengan lebih dari setengah jumlah sampel memiliki kadar troponin $\mathrm{T}$ pada rentang $>100-2000 \mathrm{ng} / \mathrm{L}$ (nilai rerata $475 \mathrm{ng} / \mathrm{L}$ ). Kadar troponin $\mathrm{T}$ dipengaruhi oleh waktu pemeriksaan tetapi tidak dipengaruhi oleh lokasi infark.
\end{abstract}

Kata kunci: infark miokard akut, troponin T, waktu pemeriksaan, lokasi infark 
Infark miokard akut (IMA) merupakan penyakit yang termasuk dalam sindrom koroner akut (SKA). Sindrom koroner akut merupakan masalah kardiovaskular yang utama karena menyebabkan angka morbiditas dan mortalitas yang tinggi. ${ }^{1}$ Infark miokard didefinisikan sebagai suatu istilah yang menunjukkan terbentuknya daerah nekrosis akibat iskemia. ${ }^{2}$ Infark miokard paling sering disebabkan oleh aterosklerosis yang menyumbat arteri koronaria yang dapat membentuk trombus, sehingga menghambat pasokan darah ke jantung. ${ }^{3}$

Menurut American Heart Association 2015 penyakit jantung koroner (PJK) di Amerika Serikat setiap tahunnya diperkirakan 635.000 mengalami serangan baru koroner (didefinisikan sebagai infark miokard atau kematian penyakit jantung koroner). Diperkirakan setiap 1 menit 24 detik akan ada satu orang yang meninggal akibat penyakit jantung koroner. ${ }^{4}$ Menurut data Riskesdas 2013 jumlah penderita tertinggi berada di Provinsi Sulawesi Tengah, sedangkan Sulawesi Utara, Aceh dan DKI Jakarta menduduki peringkat selanjutnya dengan jumlah penderita sekitar 1.236 .825 orang. ${ }^{5}$ Pada penelitian Tumade et al. ${ }^{6}$ yang dilakukan di RSUP Prof. Dr. R. D Kandou Manado periode 1 Januari 2014 - 31 Desember 2014 dari 126 kasus didapatkan kasus NSTEMI 37,8\% dan STEMI 15,1\%. ${ }^{6}$

Infark miokard harus ditangani dengan cepat dan efisien karena iskemia yang berkepanjangan dapat menyebabkan kerusakan yang ireversibel dan menentukan prognosis. ${ }^{2,7}$ Pada awal pemeriksaan EKG mungkin tidak jelas namun EKG penting untuk digunakan dalam mendiagnosis infark miokard terutama bagi tujuan terapi selanjutnya. EKG merupakan pemeriksaan yang penting untuk evaluasi awal pasien dengan nyeri dada, dimana EKG dapat memprediksi lokasi infark, luas infark maupun prognosis. ${ }^{8}$ Selain itu pemeriksaan biomarker juga dibutuhkan pada kasus "risiko rendah," pada kasus yang tidak terdiagnosis atau normal dengan EKG. ${ }^{9}$

The American College of Cardiology/
European Society of Cardiology menetapkan bahwa untuk diagnosis infark miokard akut diperlukan kombinasi antara gejala iskemik dan/atau perubahan elektrokardiografi disertai penanda nekrosis infark yaitu biomarker. Biomarker pilihan yang digunakan untuk diagnosis infark miokard akut ialah troponin jantung. ${ }^{10}$

Baheti et al. ${ }^{11}$ dalam penelitiannya menemukan variasi kadar troponin tergantung pada waktu pemeriksaan troponin dan lokasi infark. Didapatkan kadar troponin $\mathrm{T}$ meningkat pada 4-6 jam pemeriksaan dan $\geq 10$ jam, sedangkan berdasarkan lokasi infark didapatkan kadar troponin tinggi pada lokasi anterior dibandingkan lokasi lainnya. ${ }^{11}$

Berdasarkan uraian diatas, maka peneliti tertarik untuk mengetahui gambaran kadar troponin $\mathrm{T}$ berdasarkan waktu pemeriksaan troponin $\mathrm{T}$ dan lokasi infark pada pasien IMA di RSUP Prof. Dr. R. D. Kandou periode Januari-Desember 2015.

\section{METODE PENELITIAN}

Jenis penelitian ini ialah observasional deskriptif dengan pendekatan retrospektif untuk mengetahui gambaran kadar troponin $\mathrm{T}$ berdasarkan waktu pemeriksaan dan lokasi infark pada pasien infark miokard akut di RSUP Prof. Dr. R. D. Kandou selama bulan Januari-Desember 2015. Penelitian ini dilaksanakan di Cardiovascular and Brain Center (CVBC) RSUP Prof. Dr. R. D Kandou Manado. Populasi penelitian ialah pasien penderita infark miokard akut periode JanuariDesember 2015 yang diperoleh dari data rekam medik sedangkan sampel ialah pasien infark miokard akut dengan kriteria inklusi pasien dengan hasil laboratorium troponin $\mathrm{T}$, waktu pemeriksaan, dan hasil EKG. Kriteria eksklusi ialah pasien dengan penyakit ginjal kronik dan pasien yang tidak memiliki hasil laboratorium troponin T maupun EKG.

Data yang terkumpul diolah dan disajikan dalam bentuk tulisan (tekstuler) dan diagram serta dianalisis berdasarkan persentase. 


\section{HASIL PENELITIAN}

Berdasarkan hasil penelitian didapatkan dari total 61 pasien infark miokard akut pada periode Januari-Desember 2015 hanya 26 pasien yang memenuhi kriteria inklusi. Sebagian besar pasien ialah laki-laki sebanyak 19 orang $(73,1 \%)$ dan perempuan sebanyak 7 orang $(26,9 \%)$. Dari data kelompok usia didapatkan bahwa usia 5564 tahun sebanyak 10 orang $(38,5 \%)$, kemudian diikuti kelompok usia 65-74 tahun sebanyak 7 orang $(26,9 \%)$, kelompok usia 30-54 tahun sebanyak 6 orang $(23,1 \%)$ dan kelompok usia 75-84 tahun sebanyak 3 orang $(11,5 \%)$. Penelitian ini didominasi oleh pasien NSTEMI sebanyak 21 pasien $(19,2 \%)$ sedangkan STEMI 5 pasien $(80,8 \%)$. Dari data lokasi infark didapatkan bahwa yang terbanyak ialah anteroseptal dan anterolateral masing-masing sebanyak 6 orang $(23,1 \%)$, inferior sebanyak 3 orang $(11,5 \%)$, kemudian anteroekstensif, inferoventrikel kanan, infero-posterior, inferoanteroseptal dan lateral masing-masing sebanyak 2 orang $(7,7 \%)$, dan inferoanterolateral sebanyak 1 orang $(3,8 \%)$ (Tabel 1).

Hasil penelitian menunjukkan bahwa terdapat perbedaan kadar troponin $\mathrm{T}$ berdasarkan jenis infark yaitu NSTEMI berjumlah 21 orang $(80,8 \%)$ dengan nilai rerata $418,86 \mathrm{ng} / \mathrm{L}$, nilai terendah 38 nilai tertinggi >2000, dan simpang baku 502,571 sedangkan STEMI berjumlah 5 orang $(19,2 \%)$ dengan nilai rerata $481,20 \mathrm{ng} / \mathrm{L}$, nilai terendah 47 , nilai tertinggi 1616 , dan simpang baku 658,317. Hasil tersebut memperlihatkan nilai troponin $\mathrm{T}$ pada STEMI lebih tinggi daripada NSTEMI baik berdasarkan nilai rerata maupun nilai simpang baku. (Tabel 2).

Berdasarkan penelitian didapatkan sebagian besar pasien memiliki kadar troponin $\mathrm{T}$ berada pada rentang $>100-2000$ ng/L berjumlah 18 orang $(69,2 \%)$ dengan nilai terendah 114 , nilai tertinggi 1616 , dan nilai rata-rata 475 Kelompok kadar troponin T 50-100 ng/L yang berjumlah 4 orang $(15,4 \%)$ dengan nilai terendah 75 , nilai tertinggi 100 , dan nilai rerata 93,75 ; diikuti kelompok troponin $\mathrm{T}<50 \mathrm{ng} / \mathrm{L}$ yang berjumlah 3 orang $(11,5 \%)$ dengan nilai rerata $<50 \mathrm{ng} / \mathrm{L}$. Sebaliknya, kadar troponin $\mathrm{T}>2000 \mathrm{ng} / \mathrm{L}$ hanya dimiliki oleh 1 orang $(3,8 \%)$ dengan nilai rerata $>2000 \mathrm{ng} / \mathrm{L}$. (Tabel 3).

Tabel 1. Data karakteristik pasien

\begin{tabular}{|c|c|c|}
\hline Karakteristik & $\mathbf{n}$ & $\%$ \\
\hline \multicolumn{3}{|l|}{ Jenis kelamin } \\
\hline Laki-laki & 19 & 73,1 \\
\hline Perempuan & 7 & 26,9 \\
\hline \multicolumn{3}{|l|}{ Usia } \\
\hline 30-54 tahun & 6 & 23,1 \\
\hline 55-64 tahun & 10 & 38,5 \\
\hline 65-74 tahun & 7 & 26,9 \\
\hline 75-84 tahun & 3 & 11,5 \\
\hline \multicolumn{3}{|l|}{ Faktor risiko } \\
\hline Hipertensi & 6 & 23,1 \\
\hline Diabetes melitus tipe 2 & 1 & 3,8 \\
\hline Hiperkolesterolemia & 2 & 7,7 \\
\hline Rokok & 1 & 3,8 \\
\hline $\begin{array}{l}\text { Kombinasi beberapa } \\
\text { faktor risiko mavor }\end{array}$ & 15 & 57.7 \\
\hline Tidak memiliki faktor & & \\
\hline risiko mayor & 1 & 3,8 \\
\hline \multicolumn{3}{|l|}{ Jenis infark } \\
\hline STEMI & 5 & 19,2 \\
\hline NSTEMI & 21 & 80,8 \\
\hline \multicolumn{3}{|l|}{ Lokasi infark } \\
\hline Anteroseptal & 6 & 23,1 \\
\hline Anterolateral & 6 & 23,1 \\
\hline Anteroekstensif & 2 & 7,7 \\
\hline Inferior & 3 & 11,5 \\
\hline Infero-ventrikel kanan & 2 & 7,7 \\
\hline Infero-posterior & 2 & 7,7 \\
\hline Infero-anteroseptal & 2 & 7,7 \\
\hline Infero-anterolateral & 1 & 3,8 \\
\hline Lateral & 2 & 7,7 \\
\hline
\end{tabular}

Penelitian ini juga mengamati kadar troponin $\mathrm{T}$ berdasarkan waktu pemeriksaan. Waktu pemeriksaan troponin $\mathrm{T}$ yang digunakan ialah rentang waktu yang dihitung sejak onset sampai pemeriksaan troponin $\mathrm{T}$ dilakukan saat pasien pertama kali datang ke RSUP Prof. Dr. R. D. Kandou Manado. Hasil penelitian menunjukkan bahwa waktu pemeriksaan terbanyak pada rentang 9 jam dengan kadar troponin $\mathrm{T}>100-2000 \mathrm{ng} / \mathrm{L}$ sebanyak 3 orang $(11,5 \%)$ dan $>2000 \mathrm{ng} / \mathrm{L}$ sebanyak 1 
orang $(3,8 \%)$, kemudian waktu pemeriksaan 3 jam dan 4 jam masing-masing sebanyak 3 orang $(11,5 \%)$ dengan kadar troponin $\mathrm{T}$ untuk 3 jam yaitu $<50 \mathrm{ng} / \mathrm{L}, 50$ $100 \mathrm{ng} / \mathrm{L}$ dan >100-2000 ng/L masingmasing sebanyak 1 orang $(3,8 \%)$ dan 4 jam dengan kadar troponin $\mathrm{T}$ 50-100 ng/L sebanyak 1 orang dan >100-2000 ng/L sebanyak 2 orang. Didapatkan pula untuk waktu pemeriksaan 2 jam, 5 jam, 6 jam, dan 26 jam masing-masing sebanyak 2 orang $(7,7 \%)$ dimana untuk 2 jam dan 5 jam dengan kadar 50-100 ng/L dan >100$2000 \mathrm{ng} / \mathrm{L}$, kemudian untuk 6 jam dan 26 jam seluruh pasien dengan kadar $>100$ 2000 ng/L. Selain itu waktu pemeriksaan lainnya masing-masing sebanyak 1 orang yaitu 48 menit, 7 jam, 8 jam, 11 jam, 14 jam, 21 jam, 28 jam dan 72 jam dengan kadar troponin $\mathrm{T}>100-2000 \mathrm{ng} / \mathrm{L}$ kecuali untuk 72 jam memiliki kadar troponin $\mathrm{T}$ $<50 \mathrm{ng} / \mathrm{L}$ (Tabel 4).

Kemudian dilakukan pembagian rentang waktu pemeriksaan enam jam terhadap nilai rata-rata kadar troponin $\mathrm{T}$ mulai dari kadar troponin $\mathrm{T}$ yang tertinggi berada pada $18-24$ jam sebesar $1616 \mathrm{ng} / \mathrm{L}, 12-18$ jam sebesar $1374 \mathrm{ng} / \mathrm{L}, 24-48$ jam sebesar $681 \mathrm{ng} / \mathrm{L}, 6-12$ jam sebesar 536,67 ng/L, 06 jam sebesar 105,55 ng/L dan 72 jam sebesar 49 ng/L. (Gambar 1)

Tabel 2. Distribusi kadar troponin $\mathrm{T}$ berdasarkan jenis infark

\begin{tabular}{|c|c|c|c|c|c|}
\hline \multirow{2}{*}{$\begin{array}{c}\text { Jenis } \\
\text { infark }\end{array}$} & \multicolumn{3}{|c|}{ Kadar troponin T (ng/L) } & \multirow{2}{*}{$\begin{array}{c}\text { Standar } \\
\text { Deviasi }\end{array}$} & \multirow{2}{*}{ n $(\%)$} \\
\hline & Rerata & Minimum & Maksimum & & \\
\hline STEMI & 481,20 & 47 & 1616 & 658,317 & $5(19,2)$ \\
\hline NSTEMI & 418,86 & 38 & $>2000$ & 502,571 & $21(80,8)$ \\
\hline
\end{tabular}

Tabel 3. Distribusi frekuensi berdasarkan kadar troponin $\mathrm{T}$

\begin{tabular}{lcccc}
\hline Kadar troponin T (ng/L) & Rerata & Minimum & Maksimum & n (\%) \\
\hline$<50$ & $<50$ & $<50$ & $<50$ & $2(7,7)$ \\
$50-100$ & 93,75 & 75 & 100 & $4(15,4)$ \\
$>100-2000$ & 475 & 114 & 1616 & $19(73,1)$ \\
$>2000$ & $>2000$ & $>2000$ & $>2000$ & $1(3,8)$ \\
\hline
\end{tabular}

Tabel 4. Hasil tabulasi silang kadar troponin $\mathrm{T}$ terhadap waktu pemeriksaan

\begin{tabular}{llccccc}
\hline & & \multicolumn{4}{c}{ Kadar troponin T (ng/L) } & \multirow{2}{*}{ Total } \\
\cline { 3 - 5 } & & $<50$ & $50-100$ & $>100-2000$ & $>2000$ & $\mathrm{n}(\%)$ \\
\hline \multirow{6}{*}{ n $(\%)$} & $\mathrm{n}(\%)$ & $\mathrm{n}(\%)$ & $\mathrm{n}(\%)$ & $\mathrm{n}(\%)$ \\
& 48 menit & $0(0)$ & $0(0)$ & $1(3,8)$ & $0(0)$ & $1(3,8)$ \\
& 2 jam & $0(0)$ & $1(3,8)$ & $1(3,8)$ & $0(0)$ & $2(7,7)$ \\
& 3 jam & $1(3,8)$ & $1(3,8)$ & $1(3,8)$ & $0(0)$ & $3(11,5)$ \\
& 4 jam & $0(0)$ & $1(3,8)$ & $2(7,7)$ & $0(0)$ & $3(11,5)$ \\
& 5 jam & $0(0)$ & $1(3,8)$ & $1(3,8)$ & $0(0)$ & $2(7,7)$ \\
paktu & 6 jam & $0(0)$ & $0(0)$ & $2(7,7)$ & $0(0)$ & $2(7,7)$ \\
& 7 jam & $0(0)$ & $0(0)$ & $1(3,8)$ & $0(0)$ & $1(3,8)$ \\
& 8 jam & $0(0)$ & $0(0)$ & $1(3,8)$ & $0(0)$ & $1(3,8)$ \\
& 9 jam & $0(0)$ & $0(0)$ & $3(11,5)$ & $1(3,8)$ & $4(15,4)$ \\
& 11 jam & $0(0)$ & $0(0)$ & $1(3,8)$ & $0(0)$ & $1(3,8)$ \\
& 14 jam & $0(0)$ & $0(0)$ & $1(3,8)$ & $0(0)$ & $1(3,8)$ \\
& 21 jam & $0(0)$ & $0(0)$ & $1(3,8)$ & $0(0)$ & $1(3,8)$ \\
& 26 jam & $0(0)$ & $0(0)$ & $2(7,7)$ & $0(0)$ & $2(7,7)$ \\
Total & 28 jam & $0(0)$ & $0(0)$ & $1(3,8)$ & $0(0)$ & $1(3,8)$ \\
& 72 jam & $1(3,8)$ & $0(0)$ & $0(0)$ & $0(0)$ & $1(3,8)$ \\
& & $2(7,7)$ & $4(15,4)$ & $19(73,1)$ & $1(3,8)$ & $26(100,0)$ \\
\hline
\end{tabular}




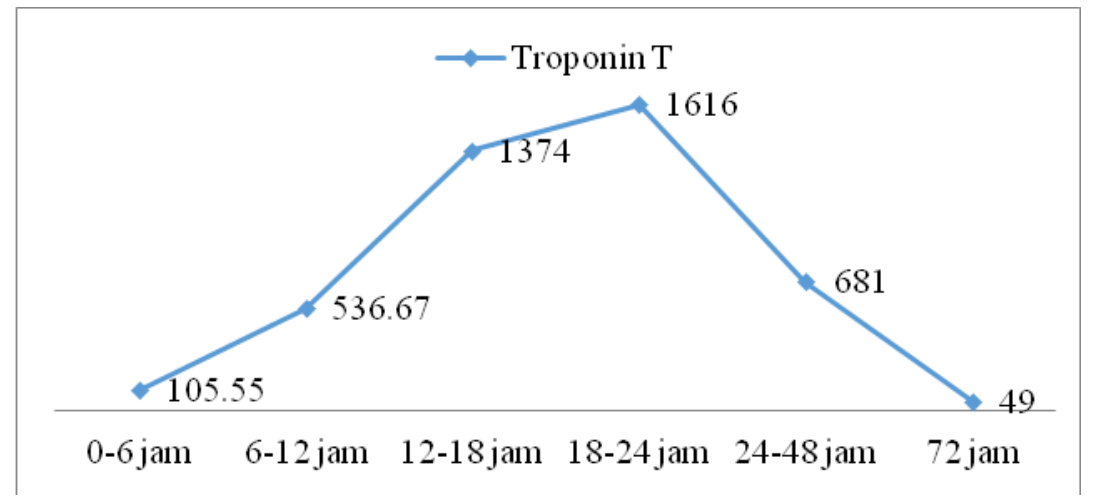

Gambar 1. Nilai rerata kadar troponin T berdasarkan waktu pemeriksaan

Pada penelitian ini dilakukan pula pengamatan terhadap kadar troponin $\mathrm{T}$ berdasarkan lokasi infark. Dari hasil penelitian diperoleh pasien terbanyak dengan lokasi infark anteroseptal dan anterolateral dengan kadar troponin $\mathrm{T}$ pada seluruh pasien berada pada rentang $>100$ $2000 \mathrm{ng} / \mathrm{L}$. Lokasi infark inferior sebanyak 3 orang $(11,5 \%)$ dengan kadar troponin $\mathrm{T}$ 50-100 ng/L sebanyak 2 orang dan $>100$ 2000 ng/L sebanyak 1 orang, kemudian diikuti oleh anteroekstensif, inferoventrikel kanan, infero-posterior, inferoanteroseptal dan lateral masing-masing sebanyak 2 orang $(7,7 \%)$ dengan kadar troponin $\mathrm{T}$ sebagai berikut anteroekstensif $<50 \mathrm{ng} / \mathrm{L}$ dan $>100-2000 \mathrm{ng} / / \mathrm{L}$, inferoventrikel kanan $>100-2000 \mathrm{ng} / \mathrm{L}$ dan $>2000$ $\mathrm{ng} / \mathrm{L}$, infero-posterior $<50 \mathrm{ng} / \mathrm{L}$ dan 50-100 $\mathrm{ng} / \mathrm{L}$, infero-anteroseptal 50-100 dan $>100$ $2000 \mathrm{ng} / \mathrm{L}$ dan lateral >100-2000 ng/L. Lokasi infark paling sedikit ialah inferoanterolateral sebanyak 1 orang dengan kadar troponin T >100-2000 ng/L (Tabel 5)

Gambar 1 menjelaskan bahwa nilai rata-rata kadar troponin $\mathrm{T}$ berdasarkan lokasi infark tertinggi pada infero-ventrikel kanan dengan nilai rerata $1363 \mathrm{ng} / \mathrm{L}$ (38\%), diikuti anteroseptal 619,67 ng/L (17\%), lateral $473 \mathrm{ng} / \mathrm{L}$ (13\%), anterolateral 395 $\mathrm{ng} / \mathrm{L}(11 \%)$, antero-ekstensif $272,5 \mathrm{ng} / \mathrm{L}$ (8\%), infero-anterolateral $191 \mathrm{ng} / \mathrm{L}(5 \%)$, inferior 115,67 $\mathrm{ng} / \mathrm{L} \quad(3 \%)$, inferoanteroseptal 111,5 $\mathrm{ng} / \mathrm{L} \mathrm{(3 \% ),} \mathrm{dan} \mathrm{infero-}$ posterior 74,5 ng/L (2\%) (Gambar 2).

Tabel 5. Hasil tabulasi silang kadar troponin T terhadap lokasi iInfark

\begin{tabular}{|c|c|c|c|c|c|c|}
\hline & & \multicolumn{4}{|c|}{ Kadar troponin T (ng/L) } & \multirow[b]{2}{*}{$\begin{array}{l}\text { Total } \\
\mathrm{n}(\%)\end{array}$} \\
\hline & & $\begin{array}{c}<50 \\
\mathrm{n}(\%)\end{array}$ & $\begin{array}{c}50-100 \\
\mathrm{n}(\%)\end{array}$ & $\begin{array}{c}>100-2000 \\
\mathrm{n}(\%)\end{array}$ & $\begin{array}{l}>2000 \\
\mathrm{n}(\%)\end{array}$ & \\
\hline \multirow{10}{*}{$\begin{array}{l}\text { Lokasi } \\
\text { Infark }\end{array}$} & Anteroseptal & $0(0)$ & $0(0)$ & $6(23,1)$ & $0(0)$ & $6(23,1)$ \\
\hline & Anterolateral & $0(0)$ & $0(0)$ & $6(23,1)$ & $0(0)$ & $6(23,1)$ \\
\hline & Anteroekstensif & $1(3,8)$ & $0(0)$ & $1(3,8)$ & $0(0)$ & $2(7,7)$ \\
\hline & Inferior & $0(0)$ & $2(7,7)$ & $1(3,8)$ & $0(0)$ & $3(11,5)$ \\
\hline & $\begin{array}{c}\text { Inferior dan } \\
\text { Ventrikel kanan }\end{array}$ & $0(0)$ & $0(0)$ & $1(3,8)$ & $1(3,8)$ & $2(7,7)$ \\
\hline & Infero-posterior & $1(3,8)$ & $1(3,8)$ & $0(0)$ & $0(0)$ & $2(7,7)$ \\
\hline & $\begin{array}{c}\text { Infero- } \\
\text { anteroseptal }\end{array}$ & $0(0)$ & $1(3,8)$ & $1(3,8)$ & $0(0)$ & $2(7,7)$ \\
\hline & $\begin{array}{c}\text { Infero- } \\
\text { anterolateral }\end{array}$ & $0(0)$ & $0(0)$ & $1(3,8)$ & $0(0)$ & $1(3,8)$ \\
\hline & Lateral & $0(0)$ & $0(0)$ & $2(7,7)$ & $0(0)$ & $2(7,7)$ \\
\hline & Total & $2(7,7)$ & $4(15,4)$ & $19(73,1)$ & $1(3,8)$ & $26(100,0)$ \\
\hline
\end{tabular}




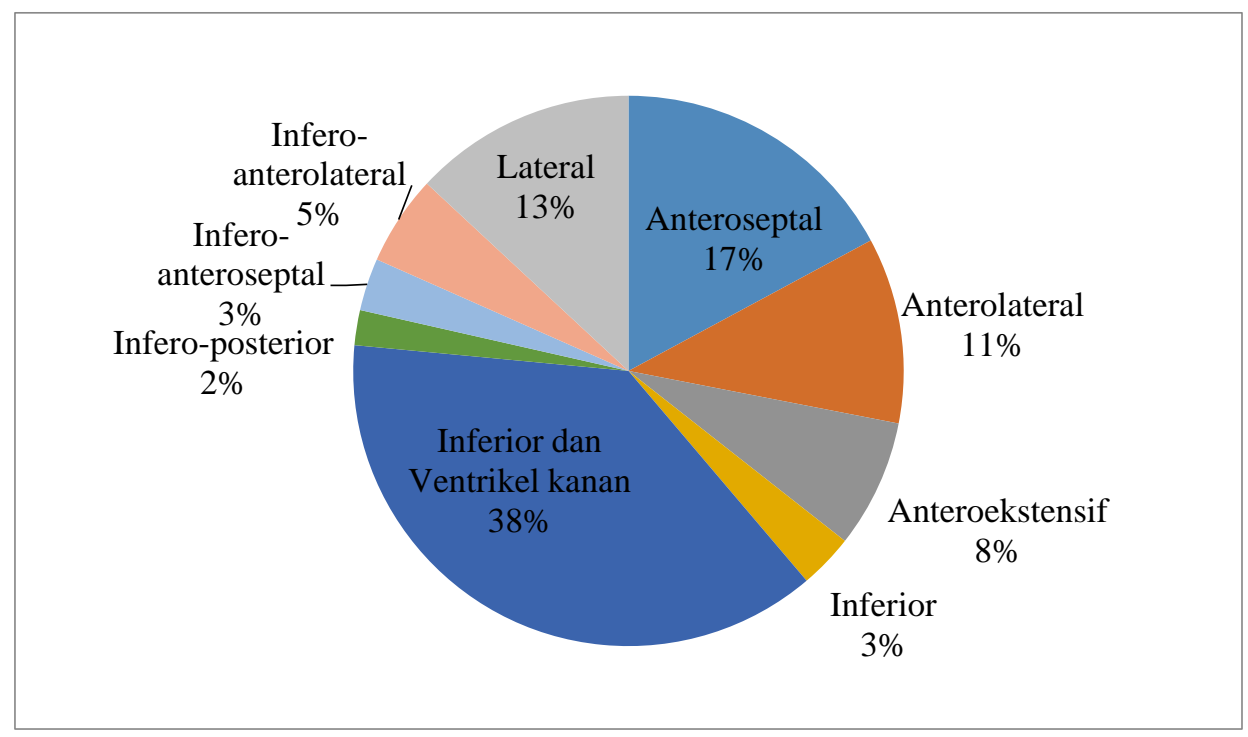

Gambar 2. Nilai rerata-rata kadar troponin T berdasarkan lokasi infark

\section{BAHASAN}

Berdasarkan penelitian didapatkan bahwa terdapat 19 pasien laki-laki $(73,1 \%)$ dan 7 pasien perempuan $(26,9 \%)$. Hasil ini sama dengan penelitian oleh Koopman et al. ${ }^{12}$ dan penelitian Rosamond et al. ${ }^{13}$ yang mengamati bahwa insiden IMA pada lakilaki lebih tinggi dibandingkan perempuan. ${ }^{12,13}$ Peran estrogen dalam mengatur beberapa faktor metabolik seperti lipid, penanda inflamasi, dan faktor koagulan memegang peranan sehingga perempuan usia sebelum menopause berisiko rendah untuk terbentuk plak aterosklerotik. ${ }^{14}$

Berdasarkan usia didapatkan kelompok usia tersering yaitu 55-64 tahun sebanyak 10 orang $(38,5 \%)$ dan terjarang $75-84$ tahun yaitu sebanyak 3 orang $(11,5 \%)$. Berbeda dengan penelitian Smolina et al. ${ }^{15}$ yang menyatakan seiring dengan bertambahnya usia terjadi peningkatan jumlah penderita infark miokard akut dan puncaknya pada usia 75-84 tahun. Hal tersebut dikarenakan seiring usia yang bertambah maka secara progresif akan terjadi beberapa perubahan pada arteri yang menyebabkan disfungsi endotel vaskular dan berhubungan dengan berbagai faktor risiko mayor penyebab penyakit kardiovaskular. Peningkatan tekanan arteri, peningkatan tekanan sistolik dan ikatan plasma low density lipoproteinkolesterol (LDL-C) akan meningkat seiring bertambahnya usia. ${ }^{16}$ Oleh sebab itu, usia yang semakin bertambah berbanding lurus dengan komplikasi PJK yang akan terjadi. ${ }^{17}$

Berdasarkan faktor risiko didapatkan jumlah pasien terbanyak dengan kombinasi beberapa faktor risiko mayor yaitu sebanyak 15 orang $(57,7 \%)$, hipertensi sebanyak 6 orang $(23,1 \%)$, hiperkolesterolemia sebanyak 2 orang $(7,7 \%)$, sedangkan diabetes melitus tipe 2, merokok, dan tidak memiliki faktor risiko mayor hanya 1 orang $(3,8 \%)$. Hasil ini selaras dengan penelitian sebelumnya oleh Memon et al. ${ }^{18}$ yang menyatakan bahwa kombinasi beberapa faktor risiko merupakan persentase terbanyak kemudian hipertensi, diabetes dan dislipidemia. ${ }^{18}$ Hipertensi dapat menyebabkan infiltrasi LDL-C kemudian peningkatan LDL-C subendotel menyebabkan glikosilasi LDL$\mathrm{C}$ yang meningkatkan kadar glukosa. Selain itu asupan lemak berlebihan akan menyebabkan peningkatan LDL-C dan merokok akan menyebabkan kerusakan dinding arteri dan oksidasi LDL-C. ${ }^{16,19,20}$ Hal tersebut yang menyebabkan interaksi beberapa faktor risiko yang dapat saling memengaruhi. $^{19}$

Berdasarkan jenis infark didapatkan pasien dengan NSTEMI lebih banyak dibandingkan STEMI yaitu NSTEMI sebanyak 21 orang $(80,8 \%)$ dan STEMI 
sebanyak 5 orang $(19,2 \%)$. Hal ini selaras dengan penelitian Yeh et al. $^{21}$ yang menyatakan bahwa insidens NSTEMI dua kali lipat lebih tinggi dibandingkan STEMI. Pemeriksaan biomarker jantung saat ini telah meningkat penggunaannya sehingga hal ini menyebabkan peningkatan jumlah kasus yang terdiagnosis NSTEMI. ${ }^{21}$

Berdasarkan jenis infark dapat dilihat bahwa kadar troponin $\mathrm{T}$ pada STEMI memiliki rata-rata kadar troponin $\mathrm{T}$ sebesar 481,2 $\mathrm{ng} / \mathrm{L}$ dengan simpang baku yang lebih besar daripada NSTEMI dengan nilai rerata $418,86 \mathrm{ng} / \mathrm{L}$. Perbedaan nilai simpang baku memperlihatkan bahwa rentang kadar troponin $\mathrm{T}$ sangat bervariasi atau menjauhi nilai rerata. Didapatkan nilai simpang baku STEMI lebih besar daripada NSTEMI. Penelitian Khan et al. ${ }^{22}$ juga mendukung bahwa STEMI memiliki kadar troponin $\mathrm{T}$ lebih tinggi daripada NSTEMI. Kerusakan otot miokardium pada STEMI bersifat transmural dan komplit sehingga menyebabkan kerusakan yang lebih luas dibandingkan NSTEMI. Terjadinya nekrosis miokardium yang menyebabkan peningkatan troponin T sehingga kerusakan yang lebih luas menghasilkan troponin yang lebih tinggi. ${ }^{23}$

Pembagian rentang kadar troponin $\mathrm{T}$ didasarkan pada alat yang digunakan. Penelitian ini mendapatkan kadar normal troponin $\mathrm{T}$ yang digunakan di RSUP Prof. Dr. R. D Kandou Manado dengan alat ukur Roche cobas h 232. Australian Point of Care Practitioner's Network dengan alat ukur yang sama membagi rentang yaitu $<50 \mathrm{ng} / \mathrm{L}, 50-100 \mathrm{ng} / \mathrm{L},>100-2000 \mathrm{ng} / \mathrm{L}$ dan $>2000 \mathrm{ng} / \mathrm{L}$. Hasil penelitian memperlihatkan kadar terbanyak yang diperoleh yaitu >100-2000 ng/L berjumlah 19 orang (73,1\%), kemudian 50-100 ng/L berjumlah 4 orang $(15,4 \%)$, selanjutnya $<50 \mathrm{ng} / \mathrm{L}$ berjumlah 2 orang $(7,7 \%)$ dan kadar troponin $\mathrm{T}>2000 \mathrm{ng} / \mathrm{L}$ hanya 1 orang $(3,8 \%)$. Secara umum pasien dengan infark miokard akut memiliki kadar troponin $\mathrm{T}$ $>100-2000 \mathrm{ng} / \mathrm{L}$ atau >200 ng/L karena kadar 50-100 ng/L diinterpretasikan sebagai possible IMA sedangkan $<50 \mathrm{ng} / \mathrm{L}$ bukan IMA. ${ }^{24}$ Hasil ini selaras dengan penelitian Wang et al. ${ }^{25}$ yang menyatakan bahwa kadar troponin $\mathrm{T}$ terbanyak ialah 140-500 ng/L dan diikuti >500 ng/L.

Pada penelitian ini dapat diamati bahwa terdapat perbedaan nilai rerata kadar troponin $\mathrm{T}$ berdasarkan waktu pemeriksaan. Nilai rerata kadar troponin T tertinggi pada 18-24 jam sebesar $1616 \mathrm{ng} / \mathrm{L}$, sedangkan kedua kadar terendah berada pada 0-6 jam sebesar 105,55 ng/L dan 72 jam sebesar 49 $\mathrm{ng} / \mathrm{L}$. Hal tersebut selaras dengan penelitian Santaló et al. ${ }^{26}$ yaitu peningkatan troponin $\mathrm{T}$ menggunakan satuan multiple of the upper reference limit. Kadar troponin $\mathrm{T}$ dinilai menggunakan pengukuran yang melebihi $99^{\text {th }}$ percentile reference cutoff dari satuan populasi normal (upper reference limit). ${ }^{27}$ Nilai upper reference limit atau kadar normal troponin $\mathrm{T}$ dalam darah sebesar $0,01 \mathrm{ng} / \mathrm{mL}^{26,28}$ Berdasarkan kurva kadar troponin $\mathrm{T}$ terhadap waktu pemeriksaan didapatkan dengan menggunakan perkalian nilai yang tertera pada kurva dengan upper reference (normal reference population) limit. $^{27}$ Didapatkan kadar troponin $\mathrm{T}$ tertinggi berada pada rentang waktu pemeriksaan 18-24 jam sebesar 400 ng/L, sedangkan kedua kadar terendah pada 72 jam sebesar $200 \mathrm{ng} / \mathrm{L}, 0-6$ jam 12,5 ng/L. ${ }^{29}$ Menurut penelitian didapatkan bahwa kadar troponin $\mathrm{T}$ juga berbeda jika dilihat sejak dari onset nyeri yaitu 0-4 jam sebesar 12,5 ng/L, 5-10 jam sebesar 112,5 $\mathrm{ng} / \mathrm{L}$ dan $>10$ jam sebesar $175 \mathrm{ng} / \mathrm{L} .^{30}$ Setiap biomarker memiliki waktu peningkatan awal, puncak dan penurunan nilai biomarker tersendiri berdasarkan hal itu pula akan terlihat kadar troponin $\mathrm{T}$ tertinggi pada 18-36 jam yang merupakan kadar puncak kenaikan troponin $\mathrm{T}$ saat terjadi kerusakan otot jantung kemudian troponin $\mathrm{T}$ akan menurun kembali normal dalam 10-14 hari. ${ }^{29,31,32}$

Berdasarkan lokasi infark didapatkan bahwa infero-ventrikel kanan memiliki nilai rata-rata kadar troponin $\mathrm{T}$ sebesar $1363 \mathrm{ng} / \mathrm{L}$ (38\%), anteroseptal 619,67 ng/L (17\%), lateral $473 \mathrm{ng} / \mathrm{L}$ (13\%), anterolateral 395 $\mathrm{ng} / \mathrm{L}$ (11\%), anteroekstensif 272,5 ng/L $(8 \%)$, infero-anterolateral $191 \mathrm{ng} / \mathrm{L}(5 \%)$, inferior $115,67 \mathrm{ng} / \mathrm{L} \quad(3 \%)$, infero- 
anteroseptal 111,5 ng/L (3\%) dan inferoposterior $74,5 \mathrm{ng} / \mathrm{L}(2 \%)$. Hasil tersebut berbeda dengan penelitian Baheti et al. ${ }^{14}$ yaitu infark anterior menghasilkan kadar troponin $\mathrm{T}$ tertinggi $84 \%$, kemudian anteroseptal sebesar $63 \%$, inferior $58 \%$, posterior $40 \%$ dan ventrikel kanan $40 \%$. Secara umum pasien yang menjadi sampel penelitian ini tidak hanya memiliki satu jenis infark saja melainkan kombinasi, sedangkan penelitian sebelumnya dengan sampel yang memiliki satu jenis infark. Penelitian Hasan dan Tarigan ${ }^{33}$ menyatakan bahwa tidak didapat-kan hubungan bermakna antara lokasi infark dan nilai troponin T. Menurut Jiménez et al. ${ }^{34}$ nilai troponin secara bermakna berkorelasi dengan luas infark dan fraksi ejeksi pada pasien STEMI dengan menggunakan single-photon emission computed tomography. Penelitian yang dilakukan Hallén ${ }^{35}$ juga menyatakan adanya korelasi yang kuat antara luas infark dan troponin jantung dimana variasi nilai troponin tiap orang tergantung dari berat miokardium (per gram berat jaringan dan per gram protein). Hal tersebut tidak berarti serta merta tidak ada pengaruh lokasi infark terhadap kadar troponin, namun disebabkan kurangnya sumber acuan lebih lanjut tentang pengaruh lokasi infark terhadap kadar troponin $\mathrm{T}$ dan berbagai keterbatasan penelitian seperti jumlah sampel yang kurang memadai. Hasil lainnya yang perlu dikaji bahwa berdasarkan penelitian ini didapatkan 2 orang yang memiliki troponin $\mathrm{T}<50 \mathrm{ng} / \mathrm{L}$ dengan lokasi infark anteroekstensif dan infero-posterior. Berdasarkan teori, infark antero-ekstensif cenderung menyebabkan kerusakan luas sehingga troponin akan mengalami peningkatan yang besar. Perlu diperhatikan bahwa untuk lokasi infark antero-ekstensif ini dilakukan pemeriksaan dalam waktu tiga jam. Hal ini menjadi dasar pemikiran bahwa waktu pemeriksaan lebih memengaruhi peningkatan troponin $\mathrm{T}$ walaupun lokasi infark cenderung menyebabkan kerusakan luas.

\section{SIMPULAN}

Berdasarkan hasil penelitian mengenai gambaran kadar troponin $\mathrm{T}$ berdasarkan waktu pemeriksaan dan lokasi infark pada pasien infark miokard akut di RSUP Prof. Dr. R. D. Kandou periode JanuariDesember 2015 didapatkan 26 jumlah sampel data rekam medis. Mayoritas pasien ialah laki-laki pada kelompok usia 55-64 tahun dengan faktor risiko kombinasi dari beberapa faktor risiko mayor. Jenis infark terbanyak ialah NSTEMI yang didominasi oleh lokasi infark anteroseptal dan anterolateral dengan lebih dari setengah jumlah sampel memiliki kadar troponin $\mathrm{T}$ pada rentang $>100-2000 \mathrm{ng} / \mathrm{L}$ (nilai rerata $475 \mathrm{ng} / \mathrm{L})$.

Hasil penelitian menunjukkan bahwa kadar troponin $\mathrm{T}$ dipengaruhi oleh waktu pemeriksaan tetapi tidak dipengaruhi oleh lokasi infark. Hal tersebut tidak berarti serta merta tidak ada pengaruh lokasi infark terhadap kadar troponin karena dapat disebabkan berbagai keterbatasan penelitian.

\section{SARAN}

Diharapkan pemeriksaan kadar troponin T lebih ditingkatkan baik dari segi ketersediaan, biaya, jenis alat pemeriksaan troponin $\mathrm{T}$, maupun pemeriksaan serial untuk tiap individu.

Untuk penelitian selanjutnya, diharapkan dapat dilakukan dengan rentang waktu penelitian yang lebih panjang dan jumlah sampel yang lebih besar agar mendapatkan hasil penelitian yang maksimal dan memuaskan.

Diharapkan penyimpanan data rekam medik lebih teratur dan terkoordinasi dengan baik untuk waktu yang mendatang.

\section{DAFTAR PUSTAKA}

1. Irmalita, Juzar DA, Andrianto, Setianto BY, Tobing DPL, Firman D, Firdaus I. Pedoman Tatalaksana Sindrom Koroner Akut (3rd ed). Jakarta: PERKI, 2015; p. 1-10.

2. Kumar V, Abbas AK, Aster JC. Buku Ajar Patologi Robbins Volume 2 (9th ed). Singapura: Elsevier, 2015; p. 329-34.

3. Aoronson PI, Ward JP. At a glance Sistem Kardiovaskular (3rd ed). Jakarta: Erlangga, 2008; p. 94-5. 
4. Mozaffarian D, Benjamin EJ, Alan S, Arnett DK, Blaha MJ, Cushman Mary, et al. AHA statistical update heart disease and stroke statistics-2015 update a report from American Heart Association. Circulation. 2015;131:e29-e31.

5. Kementerian Kesehatan RI. Data Riset Kesehatan Dasar 2013. Jakarta: Badan Litbangkes Kementerian Kesehatan RI dan Data Penduduk Sasaran, 2013.

6. Tumade B, Jim EL, Joseph VF. Prevalensi sindrom koroner akut di RSUP Prof. Dr. R. D Kandou Manado periode 1 Januari 2014-31 Desember 2014. eCl. 2016;4:223-30.

7. Backus BE, Six AJ, Bosschaert MAR, Mast EG, Mosterd A, Veldkamp RF, et al. A prospective validation of HEART score for chest pain patients at the emergency department. Int $\mathbf{J}$ Cardiol. 2013;168:2153-8.

8. Birnbaum Y, Drew BJ. The electrocardiogram in ST elevation acute myocardial infarction: correlation with coronary anatomy and prognosis. Postgrad Med J. 2003;79:490-504.

9. Stirrat CG, Cameron AD, Mills NL, Dunn FG. A clinical scoring system in undifferentiated chest pain predicting undetectable troponin concentration. J Cardiovasc Dis Res. 2013;4:98-100.

10. Arruda-Olson A, Roger VL, Jaffe AS, Hodge DO, Gibbons RJ, Miller TD. Troponin $\mathrm{T}$ levels and infarct size by spect myocardial perfusion imaging. $\mathrm{J}$ Am Coll Cardiol. 2011;4:523-33.

11. Baheti R, Laddha $P$, Gehlot RS. Value of troponin- $T$ test in the diagnosis of acute myocardial infarction. J Indian Acad Clin Med. 2002;3:55-8.

12. Koopman C, Bots ML, van Oeffelen AM, van Dis I, Verschuren WM, Engelfriet PM, et al. Population trends and inequalities in incidence and shortterm outcome of acute myocardial infarction between 1998 and 2007. Int J Cardiol. 2013;168:993-8.

13. Rosamond WD, Chambless LE, Heiss G, Mosley TH, Coresh J, Whitsel E, et al. Twenty-Two-Year trends in incidence of myocardial infarction, coronary heart disease mortality, and case fatality in 4 US communities, 1987-2008.

Circulation.
2012;125:1848-57.

14. Maas AHEM, Appelman YEA. Gender differences in coronary heart disease. Netherlands Heart J. 2010;18:598-603.

15. Smolina K, Wright FL, Rayner M, Goldacre MJ. Determinants of the decline in mortality from acute myocardial infarction in England between 2002 and 2010: linked national database study. BMJ. 2012;344:1-9.

16. Seals DR, Jablonski KL, Donato AJ. Aging and vascular endothelial function in humans. Clin Sci (Lond). 2011;120:357-75.

17. Andrés E, León M, Cordero A, Botaya RM, Magán $P$, Luengo $E$, et al. Cardiovascular risk factor and lifestyle associated with premature myocardial infarction diagnosis. Rev Esp Cardiol. 2011;64:527-9.

18. Memon AG, Shah I, Kumar S. Uric acid levels association with different risk factors of acute MI. J Cardiovasc Dis Diagn. 2016;4:1-3.

19. Patterson C, Runge M. Coronary atherosclerosis. In: Runge MS, Stouffer GA, Patterson C, editor. Netter's Cardiology (2nd ed). Philadelphia: Saunders Elsevier; 2010; p. 15-22.

20. Essien OE, Andy J, Ansa V, Otu AA, Udoh A. Coronary artery disease and the profile of cardiovascular risk factors in South Nigeria: A clinical and autopsy study. Cardiol Res Pract. 2014;2014:17.

21. Yeh RW, Sidney S, Chandra M, Sorel M, Selby JV, Go AS. Population trends in the incidence and outcomes of acute myocardial infarction. $\mathrm{N}$ Engl J Med. 2010;362:2155-65.

22. Khan HA, Alhomida AS, Habib SS, Khan AA, Ola MS, Siddiqui NJ, et al. Blood carnitine as a biomarker for acute myocardial infarction. Biomed Res. 2014;25:63-6.

23. Daga LC, Kaul U, Mansoor A. Approach to STEMI and NSTEMI. J Assoc Physicians India. 2011;59:19-25.

24. Australian PoCT Practitioner's Network. Roche cobas ${ }^{\circledR}$ h 232 Troponin $\mathrm{T}$ method and sample collection [Internet]. Australia: Australian Point of Care Practitioner's Network; 2012 Jan [cited 2016 Nov 13]. Available from: 
http://www.appn.net.au/data/sites/1/app n/02implementation/technicalresources/ troponint/rochecobash232troponintmet hodandsamplecollection.pdf

25. Wang TKM, Stewart RAH, Ramanathan T, Kang N, Gamble G, White HD. Diagnosis of MI after CABG with high-sensitivity troponin $\mathrm{T}$ and new ECG or echocardiogram changes: relationship with mortality and validation of the Universal Definition of MI. Eur Heart J. 2013;2:323-33.

26. Mangla A. Troponins [Internet]. [Place unknown]:Medscape; 2015 [updated 2015 Jan 14; cited 2016 Nov 18]. Available from: http://emedicine.medscape.com/article/ 2073935-overview\#a1

27. Archan S, Fleisher LA. From creatine kinase-MB to troponin: the adoption of a new standard. Anesthesiology. 2010;112:1005-12.

28. Conti CR. Value of borderline troponin $t$ measurements in patients with chest pain. Clin Cardiol. 2002;25:139-40.

29. Santaló Bel M, Soldevila GJ, Llanose JO. Biological markers of myocardial necrosis. Rev Esp Cardiol. 2003;56:703-20.

30. Rains MG, Laney CA, Bailey AL, Campbell CL. Biomarkers of acute myocardial infarction in the elderly: troponin and beyond. Dove Medical Press. 2014;9:1081-90.

31. Katritsis DG, Gersh BJ, Camm AJ. Clinical cardiology current practice guidelines. New York: Oxford University Press; 2013. p.181.

32. Rhee JW, Sabatine MS, Leonard LS. Acute coronary syndrome. In: Leonard LS, editor. Pathophysiology of Heart Disease (5th ed). Philadelphia: Lippincott Williams \& Wilkins, 2011; p. 162,167,172-6.

33. Hasan H, Tarigan E. Hubungan kadar troponin $\mathrm{T}$ dengan gambaran klinis penderita sindroma koroner akut. Majalah Kedokteran Nusantara [Internet]. 2005 Des [cited 2016 Agustus 31]. Available from: Library USU: http://library.usu.ac.id/download/fk/pen ydalam-elias\%20tarigan.pdf

34. Jiménez RF, Romero PL, Barrientos AS, Rubira JC, Ortiz AF, Fuster V, et al. Troponin release overestimates infarct size in presence of left ventricular hypertrophy. J Am Coll Cardiol. 2012;60:640-1.

35. Hallén J. Troponin for estimation of infarct size: what have we learned? Cardiology. 2012;121:204-12. 